\title{
A Comparative Assessment on the Role of Private Investment in Poverty Reduction in Illubabor and Jimma Zones, Oromiya National Regional State, Ethiopia
}

\author{
Kaleb Amanu Tamene'; Bizuayehu Daba ${ }^{2}$ \\ Department of Governance and development studies, Jimma university, Ethiopia \\ Email: kalebamanu@yahoo.com¹; Bizuayehud539@gmail.com² \\ Corresponding author: Kaleb Amanu Tamene
}

http://dx.doi.org/10.18415/ijmmu.v7i2.1528

\begin{abstract}
The research was assessing the role of private investment in poverty reduction in Jimma and Illibabor zones comparatively. There was almost little study was done in this areas and the research intended to fill such hole. For this purpose, necessary and careful literature reviews were done before. This research is workout by using a qualitative approach of research methodology and as far as the sampling technique concerned, we employed non probability sampling technique. From non probability sampling, purposive sampling technique was chosen. To this effect, Jimma and Illuababor Zones were purposively selected because of their prominence to Jimma university and which helps to save time and to implement one of the well known axiom of JU and that is "we are in the community" to promote the livelihoods of the community. Finally, the data gathered by using primary and secondary sources and the results proved that private investment is very important for the alleviatiation of poverty. For sure, there is a complementary relationship between private investment and poverty reduction. Moreover, the study finally recommends that Jimma and Illubabor zones should seriously work in creating enabling environment for private investment.
\end{abstract}

Keywords: Comparative; Determinants; Private Investment; Poverty Reduction

\section{Background of the Study}

Private investment connected to capital accumulation goes back to pre- Classical views (Faramarz, 2008:19). Indeed, the mercantilists were, in a way, the first to reflect on attracting foreign capital and to set up investment plans. In 1991, Ethiopia's transition from socialism towards free market economy brings a new era for diversification of investment. Since then, the government has made policy reforms, such as liberalization of foreign trade, decentralization of economic and political power, deregulation of domestic price and devaluation of the national currency. In addition, the investment code has been amended several times in order to meet the demands of both domestic and foreign investors (Solomon: 2008:2). Accordingly, Ethiopia is one of the developing countries that it is highly endowed with fertile land and has developed a very investor-friendly environment for the last decade through strong changes in their national policy framework. Hence, investment plays a significant role for 
promoting economic development and reducing poverty. Sustainable economic growth is determined by the rate of investment which in turn is mainly determined by the national savings level.

Despite Private Investment is a key to long-term poverty reduction (Tibebu, 2014) private investment, in levels and as a percentage of GDP in Ethiopia has shown an inconsistent trend for some periods during 1970-2012. This is a problem, firstly because private investment matters for growth, and secondly because low private investment increase vulnerability in the economy (ibid). From time to time the importance of domestic private investment could not be disheartenment. Normally the history of private sector in Ethiopia dates back to the reign of emperor Menelik II with acquisition of land, however it starts to develop during emperor Haile sillasie(ibid). Even during that time, much of the private sector clustered around land and related activities. Contrary to the previous governments, the military government denies the role of private sector. FDRE gives high emphasis to the development of domestic private investors in cognizant of the role of private sector in general and the role of domestic private investment in particular to engendering poverty reduction (Solomon, 2001). However, the level of private sector in general and domestic private investment in particular in Jimma and Illubabor zones are still at its embryonic stage (ibid).

Many studies have been conducted with regard to the role of private investment in promoting poverty reduction in Oromiya National Regional state. However, there is very little research has done in the selected site. For instance, as far as the selected area is concerned, the only available study we got in websites is a work done by Yohannes Belete entitled in assessment on Factors that Contribute to Low Investment Activities in Jimma Zone. Accordingly, there were no much more studies including comparative studies done before in Jimma and Illubabor zones. So that, a gap of knowledge on private investment and poverty reduction in these zones. So that, the study has conducted in order to fill the gap and which makes this research new.

\section{Objectives of the Study}

1/To identify the major determinants of Private Investment in Illubabor Zone and Jimma Zone.

2/ To examine the contribution of Private Investment in Poverty Reduction Illubabor Zone and Jimma Zone

3/To compare the role of Private Investment in Poverty Reduction Illubabor Zone and Jimma Zone

4/To identify major investment activities in the two zone

\section{Methods}

This research conducted based on qualitative approach. Moreover, qualitative methodology emphasizes on quality, depth and understanding, instead of the statistical representativeness and scientific rigidity. The most appropriate methods for the research therefore depend on the questions the researcher wants to ask and the sort of information the researcher wants to make. Not everything can be quantified or quantified easily, and an advantage of qualitative research is that it can investigate these things. For instance, an individual experience is found out easily by employing qualitative method of research. Also, individuals can be studied in more depth in qualitative approach since the participants are able to provide the desirable data in their own words and in their own way. In qualitative research the researcher is central where he/she is the primary instrument of data collection. Unlike the quantitative methodology where data are collected through questionnaires, in qualitative research data are mediated through the researcher or the human instrument (Bogdan \&Taylor, 1975). 
The research design of this paper is case study. The rationale behind using this design is the researcher's need to see the case in depth and the research is descriptive in its nature. Moreover, this type of research design type is more appropriate for individual researchers since it gives an opportunity for one aspect of a problem to be studied in some depth within a limited time scale. There are a number of different data generating tools that are available out there and one should be selective which is most likely to meet the objectives of the research and gather the correct type of information (Douglas, 1985). There are two types of data to be used in this study. These are primary and secondary data. Both data were collected from different sources. Primary data were obtained through key informant interview, focus group discussion and personal observation. On the other hand, secondary data were gathered based on techniques like document analysis, and browsing internet websites.

The researchers used non probability sampling technique. From non-probability sampling, purposive sampling is selected. This non-probability sampling technique selected based on knowledgeable persons with the desired expertise was suitable for the study. Hence, limited participants were purposefully selected and an in-depth data were collected from each of them. The researchers employed their utmost effort to incorporate the opinions of interviewees.

The researchers selected only five private investment sectors and they are coffee processing, construction of buildings, oilseeds, livestock and manufacturing. The interviewees of this research were selected based on their organizational or individual relevance to the study. In other words, the eligibility criteria for the participants were: experience, expertise knowledge and academic relevance to the research questions. Accordingly, Jimma and Illuababora zones were purposively selected at first stage because of their proximity to the Jimma university so as to save time and to implement one of the well known motto of JU and that is "we are in the community" to promote the livelihoods of the community. Hence, 2 out of 17 weredas of Jimma zone and 2 out of 18 woredas of Illubabor zone were purposefully selected. Thus, for the sake of representing the zones as a sample we purposively selected two (2) woredas from each zone so that from illubabor zone we were selecting Mettu and Bedelle. From jimma zone, Agaro and Sekoru woredas are selected. Even tough jimma zone investment bureau is found in Jimma town, the town is currently become especial woreda and for that matter jimma town is out of the site selection.

\section{Discussions and Results}

\section{1 Investment Activities in Selected Studied Areas}

\section{A) Coffee Processing}

These two studying zones are naturally endowed and gifted for coffee production and even some say that coffee as a plant and its tradition to drink started in Jimma/keffa. For the sake of exporting coffee, these two zones have a lion share for Ethiopian foreign exchange. Based on a statistics obtained from both key informant interviewee in Jimma and Mettu by representing the two zones investment office top managers, Coffee is the number one investment activity both in Illubabor and Jimma zones. However, in comparative words, Jimma zone has got a better dominance business in coffee than Illubabor zone by taking $65 \%$ of the whole private investment sector. Moreover, many investors registered in coffee processing, washing harvesting and in collecting activities.

This shows how much coffee is not only historically but also now really attached to the investors aspiration and vision. Consequently, it is true that coffee plays indispensable role in poverty reduction in both zones by opening job opportunity and income generation for many workers especially for women's in the two zones. In terms of significance or level of bringing revenue the most important sector is coffee processing agro industry in both zones and that is the similarity between the two zones. 


\section{B) Construction of Buildings}

According to the FGD and key informant interviewees, among the investment sectors, construction is the most important investment engaged area in the study since it is basically due to the increased demand for commercial building and infrastructures for the society. Most of the time, in the two zones, Construction activities are found for the sake of like hotel and cafeteria and sometimes for mixed use. Based on the data found from key informant interview and FGD, both zonal investors have a better bureaucratic access to get land and to build what they agree with the government. From the interview from Jimma zone investment office head, as a problem he mentioned that, most investors from Jimma zone have flee and try to invest in Addis Ababa and the other investors left at home(local) they don't start their construction on time which has been agree to start early.

\section{C) Manufacturing}

According to the informants, among the investment sectors, Manufacturing (which is the most appreciated and funded sector of all now a days for the sake of promoting industrialization). Among the most notable manufacturing areas leather and related, manufactured of bottled water, flour ,dairy powder milk cheese and butter, manufacturing of food products, meat processing, milk processing and so forth.

The local government is encouraging the manufacturing sector is that the sector is expected to create employment opportunities but it is below what they planned. The main bottlenecks of the investors that are involved in the manufacturing sector; not to create employment opportunity as per their proposed plan are; seasonality of the demand to their production/service, financial problem, and absence of skilled man power. Some of the challenges that the investors faced during land acquisition process are; bureaucratic procedures, provision of land, access to loans, governance issues and availability of trained human resources. Financial institutions are; very weak and time consuming banking service, insufficient credit provisions. Fortunately; Most of investors have got various incentives including duty free import, provision of land by initial lease price, tax incentive/holiday, credit provision and facilitation.

\section{D) Oilseeds and Crops}

Agriculture is the backbone of the Ethiopian economy and so does for Jimma and Illubabor zones. The fertile soil, arable land available and favorable weather condition of the two zones are the reliable features for attracting the potential investors. Generally, based on the data found from informants and personal observation, When we compare the two zones private investment role for poverty reduction, we consider so many variables and for instance, In terms of priotization, both zones are giving priotization for manufacturing industry because of promoting industrialization even though most investors are not interested in it due to the fact that the sector needs much amount of finance. In the two zones there is no large scale noticeable manufacturing industry except Bedelle brewery which found in Illubabor zone. The rest of manufacturing industry is just related to coffee and milk processing, leather and garment processing are some of them.

\subsection{Determinants of Private investment in the Studied Areas}

There is a relationship between determinants of investment and poverty reduction. Determinants of Private Investment are helpers to know what factors reduce or aggravate poverty. Because of the significance and importance of the private sector investment in stimulating poverty reduction, policies should designed to attract private investment should be deep enough to stimulate poverty reduction. The managers of Illubabor and Jimma zone investment office should understand the long run positive effect of private investment and make others aware of the positive impact of private investment for poverty reduction. Moreover, the local government of the two zones should take supplementary reforms that will 
improve the zones poor investment climate, (for instance: poor infrastructure, particularly, Power shortage; poor transport; poor telecom connectivity of business locations and lack of efficient tax Administration), that promotes private sector development, in supportive of entrepreneurial endeavor and with a bias towards expansion of business activities.

As per the informants and a serious of discussions held the researchers brought the idea that it has to be done to attract more nongovernmental investors. So that, doing the following mechanisms which considered as determinant factors will adjust the reduction of poverty through promoting private investment.

\subsubsection{Policy Advocacy}

As far as investment promotion is concerned, policy advocacy is important to improve the quality of the investment climate and identifying the views of private sector in this area. Over the last consecutive years, the administrators manifested such a paramount interest in advocating for the private sector to influence policy reforms. However, there are still some opportunities available to investment promotion in the two zones namely robust governance by rule of law and absence of corruption, access to markets, untapped opportunities in agriculture, energy, tourism and available infrastructure facilities, and sustained poverty reduction. Finally, we have noticed that there is a great need for strong ties between Policy advocacy and promoting investments. This could be manifested in some of investment promotion activities aimed at national image building, investor targeting, policy advocacy, and investment generation.

To achieve poverty reduction in the two specified zones, the zone investment bureau should initiate, in partnership with the people and initiate some policies aimed at propelling research and development, conducting investment promotion activities, transfer of knowledge and technology within private industries in jimma and illubabor zones.

\subsubsection{Infrastructure}

According to the informants, the role of infrastructure for investment and in turn investment for poverty reduction is indispensable. However, in most towns of the zone we selected there is low-level of infrastructure, constructions of road including on and off of electricity, water service which is completely annoying for the investment activities that runs in the two zones. In the side of the municipal and investment office managers we have been asking the same question about infrastructure and they mentioned that the fact remains true but the thing is we all knows that there is constant and overwhelming improvement has been doing in the past years in these zones.

\subsubsection{Level of Bureaucracy and Investors Determination to start at the exact time}

According to the informants there are two things that are raised as a problem from two sides (government and private investor and that is from government angle there is much more bureaucracy which makes things untimely and stagnate to start and promote investment centered development plans. On the other hand from the investors side, they are taking much long period of time to start the investment since the policy says every investor who is in the list of enrollment must start a business up to $\operatorname{six}(6)$ month and if they take more than that the investment field will taken away from them.

\subsection{The Role of Private Investment in Poverty Reduction}

Private investment of all forms has the potential to make a positive impact. However, investing in small-scale producers, particularly when it becomes in two zones is especially important. There is, 
therefore, an opportunity for public and private investment to make a substantial positive impact on the livelihoods of small-scale food producers. The zone investmentbureau has a responsibility to enable, regulate, and enforce the interests of those who are less powerful in markets. Unfortunately, investment promotion policies generally favor large-scale investments (including large-scale land acquisitions), instead of positive agricultural investment. There is a host of investment promotion policies, including investment liberalization, facilitation, protection and incentives. So far, these government policies have largely helped facilitate access for investors (including access to land) to the detriment of small-scale producers. In Jimma and Illubabor zones, the impact of private investment for poverty reduction has been greater than that of the public sector investment. The sector has an important role in complementing government's endeavors to accelerate poverty reduction. Particularly, the socio-economic roles that industrialists play were more crucial.

According to the informants, acknowledged the contributions of private investment in sustaining poverty reduction. The sector has a huge potential both in improving the livelihoods of the people and job creation. It creates opportunities, and increase incomes of the poor. In turn, the sector would generate the revenues that governments need to allocate to other social services such as health, education and basic infrastructural development. However, according to the FGD and our personal observations, the participation of the private investments in the two zones was too low due to various reasons. This would lead to under performance in exploiting the potential in the sector. It would also be the main cause for insufficiency, low initiations for innovation and inadequate job opportunities for citizens. Obviously, vigorous and sustained poverty reduction that is fueled by active participation of private investors and entrepreneurship is needed to speed up the implementation of the development plan. Thus, creating mutual understanding between the government and industrialists would enable them have common position towards nation's development goals and also to look for alternative solutions for possible hindering factors.

Private investment enhances the development of country through reduction of poverty, increasing the accumulation of fixed capital, creation of employment opportunity, increasing the revenue of government. This requires creating conducive business environment. The paper examined the challenges and prospects of domestic private investment in illubabor and Jimma zones. The study investigated challenges such as lack of start-up capital, limited access to land, weak marketing infrastructure, long bureaucratic procedures, limited access to credit, and corruption that were determining factors for domestic private investment in the studied areas.

It is a plain fact that there is also a positive relationship between poverty reduction and private investment. According to our key informants, FGD and our personal observation we deduce that there is a lot of employment opportunities, technological and skill development opened for the citizens of the two case study areas (zones). For sure, there is a growing and a complementary relationship between the two which means economic growth (poverty reduction) and that of private investment. Following an appropriate interest rate policy to boost saving on the one hand and measures to widen and modernize the scope of private investment is essential. Moreover, sound macroeconomic policies to cheek uncertainties, mechanisms to curve luxurious private consumptions as well increasing efforts for debt giving and relief there by to reduce future indebtedness are some of the presumed measures to be taken so as to boost private investment in the two zones.

\section{Conclusion}

Based on the findings of the study, the following conclusions are derived. A strong private sector particularly private investment is an important engine for stimulating reducing poverty. The greater the share of private investment in the economic sector of jimma and Illubabor zones, the higher the average 
growth rate of poverty reduction. This is manifested by the creation of more employment opportunities, higher output and good standard of living of people.

In the two specified zones, there is the practice of private investment even though it is not like being as expected due to absence of skilled human power in some specific areas of specialization, and Interruption of electric power and shortage of water supply. Moreover, most of the infrastructures were ranked as not satisfactory for the whole towns though there is a change from time to time. As other determinant factors such as telecommunication, health center and post office services were ranked as good. The rest infrastructures; water, electricity and road are ranked as not satisfactory. With regard to water supply for the whole towns it is was ranked as poor according to the respondents.

As interview result of officials and secondary data, trend of the investment has increased in the last consecutive years in the towns. Moreover, as profile of investors registered shows, the number of registered investors is increasing in the region. Investors usually report as the trouble makers in investment is government. But it is not possible to conclude that the problems are emerged only from government. Based on the top managers speech the researchers understood that, investors have many problems such as; they don't start operation as per their proposed plan, changing of sector after obtaining of license, financial incapability, providing unreal deposit account, hiring non professionals (most of the investors manage their business by themselves), inappropriate land management inefficient utilization of natural resources, lower wage rate, illegal expansion of land, and using land for another purpose.

\section{Recommendations}

The researchers would like to comment that unpredictable and inefficient investment climate which could be due to reasons such as frequent changes of investment policies and requirements, inefficient bureaucracy, prolonged poor governance and rampant corruption among others, would deteriorate investors' confidence and appetite. Thus, based on these findings, the following policy implications are forwarded like undertaking public investment in a way that could ease bottlenecks that undermine private investment, of course with adequate attention to its adverse effect of 'crowding out', Enhance the real per-capita income of people by creating various employment opportunities and income generating means, efficiently utilize external sources of finance (loan) for productive investment activities, Ensure macro-economic stability by containing the inflationary trend persisted over a longer period, create fertile investment environment by ensuring consistent investment policies and requirements, by creating clear and efficient bureaucracy and good governance at all levels, and by opening more investment opportunities for private investors. The zonal governments should give priority to investments in key public goods, such as capacity building, infrastructure, and research systems, to help small-scale producers who are not yet market-ready ensure their food security and livelihoods. Women producers must be empowered through targeted measures. To achieve positive agricultural investment, regulations to protect the environment and incentives to encourage sustainable agriculture are also needed. Environmental impact assessments and the regulation of pollution are essential first steps to making market systems environmentally sustainable, but incentives to shift toward sustainable production are also desperately needed. Private sector investment can play a vital role in delivering inclusive environmental sustainability and poverty reduction. However, in order to do so, it must be adequately regulated and should adhere to some key principles, such as focusing on local food markets, working with producer organizations and respecting the rights of small-scale producers, workers and communities. Last, but not least, the researchers suggests the need to conduct a wide-ranging study on the role of private investment to reduce poverty in Jimma and Illubabor zones to illustrate supplementary proper policy actions and decisions. 


\section{References}

Adeleke Gabriel. (2013). Private Investment and Sustainable Economic Growth in Economic Community of West African States. Development Policy Research, western Michigan University. Distribution and Employment. PH.D Dissertations. Fribourg, Switzerland.

Akinlo A.E. (2004). FDI and Economic Growth in in Nigeria: An Empirical Investigation. Journal of Policy Modelling,Vol. 26, pp. 627-639.

Ayanwale, A.B. (2007). FDI and Economic Growth: Evidence from Nigeria. AERC Research Research Paper 165. African Economic Research Consortium, Nairobi.

Beirhanu Nega and Kibre Moges. (2003). International Competitiveness and the Business International Competitiveness and the Business Climate in Ethiopia. Ethiopian Economic Association Working Paper No.1/2003.

Buthe and Milner. (1994). Foreign Direct Investment and International Institutions, available nathanjensen.wustl.edu/me/files/ButheMilner.pdf accessed, 21 December 2011.

Climate in Ethiopia. Ethiopian Economic Association Working Paper No.1/2003.

Creswell, John W. (2009). Research Design: Qualitative, Quantitative, and Mixed Methods.

Datt, G. And Ravallion. (2002). Is India's Economic Growth Living the Poor Behind?'World Bank Washington D.C. Mimeo.

Dechassa Lemessa. (1999). Prosperity Fades case in Jimma and Illubabor Zones of Oromia Region,jimma.

Dollar D. And Kraay A. (2002). "Growth is Good for the Poor”. Journal of Economic Growth. 7,195-225 ed.). Thousand Oaks: Sage Publications.

Erden and Holcombe. (2005). "The Effects of Public Investments and Private Investments in Developing Economies". Public Finance Review, Vol. 33 No5, Sept. Ethiopia, Maastricht, the Netherlands. MA Thesis.

Faramarz Akrami. (2008). Foreign Direct Investment in Developing Countries: Impact on Journal of Asia Entrepreneurship and Sustainability. Golden Gate University.

Kenya Airways: A Case Study of Privatization, by Samuel Oyieke, Research Paper 119.

Mwilima, Ntwala. (2003). Foreign Direct Investment in Africa. Labor Resource and Nations, New York, USA.

Nkoro, E. and Uko, A. K. (2012). "Foreign Capital Inflows and Economic Growth in Nigeria: An Empirical Approach, Asian Journal of Empirical Research, Vol. 2(5), pp 149- Pennsylva.

Philip Mpango. (2015). The Role of Investment in Economic Development and Growth Strategy of Tanzania, Research Institute (LaRRI). Africa labor Research Network.

Solomon D. (2001) ."Private Sector Development in Ethiopia”,Center for African development. 
Solomon Mamo Woldemeskel. (2008). Determinants of Foreign Direct Investment in Ethiopia.

Swapna S. Sinha. (2007). Comparative analysis of FDI in China and India. Volume III, Issue 2.

UNCTAD. (2002). Ethiopia: Investment and Innovation Policy Review, United Nations.

UNCTAD/ICC. (2000). An Investment Guide to Ethiopia: Opportunities and conditions.

UNHABIT. (2011). "Infrastructure for Economic Development and Poverty Reduction in Africa". United Nations Human Settlements Program. available at www.unhabitat.org.and date access June 2,2016 .

United Nations. (2006). The Millennium Development Goals Report. United Nations, New York and Geneva.

Yohannes Belete. (2006). Assesment on Factors that contribute to low investment activities injimma zone,jimma university,available at www. http//opendocs.ids.ac.uk/opendocs/handle, and date access April17, 2016.

\section{Copyrights}

Copyright for this article is retained by the author(s), with first publication rights granted to the journal.

This is an open-access article distributed under the terms and conditions of the Creative Commons Attribution license (http://creativecommons.org/licenses/by/4.0/). 